\title{
Nursing and Midwifery Students' Perception and Experiences of Mentorship: A Systematic Review
}

\author{
Crecious Mutinta Muleya ${ }^{1}$, Jayne Marshall ${ }^{2}$, Cathy Ashwin ${ }^{3}$ \\ ${ }^{1}$ Department of Nursing Sciences, School of Medicine, University of Zambia, Lusaka, Zambia \\ ${ }^{2}$ Faculty of Health, Social Care and Education (HSCE), St Georges, University of London/Kingston University, \\ Cranmer Terrace, London, UK \\ ${ }^{3}$ MIDIRS, University of Nottingham, Bristol, UK \\ Email: ${ }^{*}$ cmmuleya@gmail.com, j.marshall@sgul.kingston.ac.uk, c.ashwin@midirs.org
}

Received 15 May 2015; accepted 26 June; published 30 June 2015

Copyright (C) 2015 by authors and Scientific Research Publishing Inc.

This work is licensed under the Creative Commons Attribution International License (CC BY).

http://creativecommons.org/licenses/by/4.0/

(c) (i) Open Access

\section{Abstract}

Background: Mentorship has been the model adopted by many countries to support learning and assessment of students in the clinical placement. It has remained uncertain whether or not it has a lot of positive benefits for the students' experiences during placement as there have been divided opinions among researchers. Objective and review question: The objective of this qualitative systematic review was to explore the perceptions and experiences of nursing and midwifery students regarding mentorship during clinical placement. The question of the review was: what are the perceptions and experiences of nursing and midwifery students regarding mentorship during clinical placement. Methods and materials: Electronic data bases, journals and grey literature were searched for relevant studies and seven qualitative studies were systematically included in the review. The Joanna Briggs Institute-Qualitative Assessment and Review instrument (JBI-QARI) was used to critically appraise the studies. Data extraction was done using the JBI-QARI Data Extraction Tool. A thematic analysis was used to synthesise the findings. Findings: The findings suggest that there are still gaps within the mentorship programme that could have an impact on the students' learning experiences during clinical placement. From the themes identified which include: need for feedback, hands on practice, continuity of mentorship and mentor-mentee relationship, the reviewers concluded that such areas of mentorship require attention in order to benefit the students. Conclusions: It can therefore be concluded that there are many lessons to be learnt in order to continue improving mentorship. It is also clear that mentorship will be beneficial to students if a good relationship is established between the mentor and mentee, as this is the beginning of the experience. All staff members should be willing to support students in learning

\footnotetext{
"Corresponding author.
} 


\title{
for them to develop the knowledge, skill and attitudes that are necessary to their learning.
}

\section{Keywords}

\author{
Mentorship, Preceptorship, Clinical Supervision, Experience, Perception, Systematic Review
}

\section{Background}

Nursing education has a mandate to prepare students to practice safely, accurately and compassionately in a myriad of health care settings [1]. The clinical setting is considered as one of the most valuable educational resources for students as it helps them to gain practical knowledge and skills to practice their discipline. This requires adequate support and supervision. Dean and Kenworthy [2] suggest careful planning by the education provider for the students to gain the maximum benefit from the learning opportunities [2]. The need to have adequate supervision and support for students during clinical placement has always been emphasised by various international bodies like International Confederation of Midwives (ICM), United Nations Population Fund (UNFPA) and World Health Organisation (WHO) [3]-[5].

Mentorship has remained a better option than apprenticeship for supporting and supervising students during clinical placement [6]. It is worth mentioning that most African countries, including Zambia, do not have formalised mentorship programmes for students in the clinical practice setting as indicated by Dennis-Antwi [7]. According to Cope et al. and Napthine students require regular personal contact and interaction with the mentor for them to develop tacit knowledge [8] [9].

Anderson and Shannon (1988) describe mentorship as a nurturing process which involves an experienced and more skilled person who acts as role model and who teaches, encourages and counsels another less skilled and less experienced person so that the latter is able to develop professionally [10].

Although some countries (for instance UK [11], Cyprus and Sweden) have adopted mentorship as a method of supporting students in the clinical placement, many researchers still doubt whether it is good or harmful for students [12]. The experiences of students towards mentorship have remained a debatable question as there are conflicting results from individual studies.

The systematic review reported in this paper brings together results of qualitative studies in which experiences and perceptions of students regarding mentorship are considered. The results of the review can provide guidance and a template for the nursing and midwifery bodies in other countries to develop mentoring programmes that are designed to benefit the student.

\subsection{Review Objective}

The main objective was to conduct a systematic review of best qualitative evidence available on perception and experiences of nursing and midwifery students regarding mentorship during clinical placement.

The specific objectives were:

1) To identify relevant research available for the review.

2) To synthesise the evidence on nursing and midwifery students' perception and experiences of mentorship during clinical placement.

3) To systematically appraise the report of the review.

4) To make recommendation to the relevant bodies on the issues arising from the review.

\subsection{Review Question}

What are the perceptions and experiences of nursing and midwifery student regarding mentorship during clinical placement?

\section{Methodology}

A systematic review was performed on qualitative evidence to quickly assimilate a large amount of information 
about the relevant topic.

The Population/participants phenomena of Interest Context Study design (PICOS) framework by Centre for Reviews and Dissemination (CRD) is used to formulate the review question as it is applicable to qualitative review [13].

Population: Nursing and Midwifery students.

Phenomenon: Mentorship experience.

Context: Clinical placement.

Study design: Qualitative.

\subsection{Search Strategy}

A comprehensive and systematic literature search in PubMed, Embase, Web of Science, and the Cochrane Library was conducted to identify all available literature on students' mentorship experiences. The Cumulative Index to Nursing and Allied Health Literature (CINAHL), Medical Literature online (Medline) and MedNar were also searched using the key search terms. To avoid publication bias, other search strategies such as scanning conference proceedings contacting researchers working in the area and scanning grey literature for unpublished studies was used. Unpublished studies were searched in data bases such as the Networked Digital Library of Theses and Dissertations (NDLTD) and the Australian Digital Theses Programme.

Key journals were also searched for relevant studies to identify recent publications that may not have been indexed by data bases. The journals searched include the International Journal of Nursing Studies, Nursing Education Today, Journal of Clinical Nursing, Midwifery, Journal of Advanced Nursing and Nursing Education in Practice. Alerts were set for any relevant studies published during data collection stage. Other sources searched include World Wide Websites and search engines such as Google Scholar.

\subsection{Selection}

The combined search strategies from all sources yielded 1417 studies (Figure 1). Following reading of titles and abstracts 789 studies were eliminated because they were duplicated. The remainder of the studies were read for the second time and a further 592 titles were eliminated as they seemed not to be relevant.

This resulted in a total of 36 articles which needed to be assessed against the inclusion and exclusion criteria (Table 1). Due to the differences in terminologies among countries and that some countries use the terms "preceptorship" and "mentorship" interchangeably studies that used the two terms were included. Out of the 36 studies, only seven (7) met the inclusion criteria (Table 2) and 29 were excluded because they were not congruent with the review objectives. The list of excluded studies has been written for transparency purposes (Appendix 1).

Table 1. Inclusion and exclusion criteria of studies.

\begin{tabular}{|c|c|c|}
\hline \multicolumn{3}{|c|}{ Inclusion and exclusion criteria } \\
\hline Parameters & Inclusion criteria & Exclusion criteria \\
\hline Population/participants & $\begin{array}{l}\text { Studies which focus on or nursing } \\
\text { and midwifery students }\end{array}$ & $\begin{array}{l}\text { Studies focusing on newly qualified nurses and midwives, } \\
\text { medical student and other allied health worker students }\end{array}$ \\
\hline Phenomenon & $\begin{array}{l}\text { Studies that focus on student mentorship/ } \\
\text { preceptorship experiences }\end{array}$ & $\begin{array}{l}\text { Studies that focus on preceptorship experience of } \\
\text { newly qualified nurses and midwives }\end{array}$ \\
\hline Methodology & $\begin{array}{l}\text { Studies which reported on findings which use } \\
\text { qualitative methods (data collection \& analysis) }\end{array}$ & $\begin{array}{l}\text { Studies which DID NOT include qualitative } \\
\text { methods of data collection \& analysis }\end{array}$ \\
\hline Language & Studies written in English & Studies not written in English \\
\hline Location & All & All \\
\hline Publication date & Studies published from 1990 (inclusive) onwards & Studies published before 1990 \\
\hline Type of studies & Primary research & Book reviews, opinion pieces, literature reviews \\
\hline
\end{tabular}




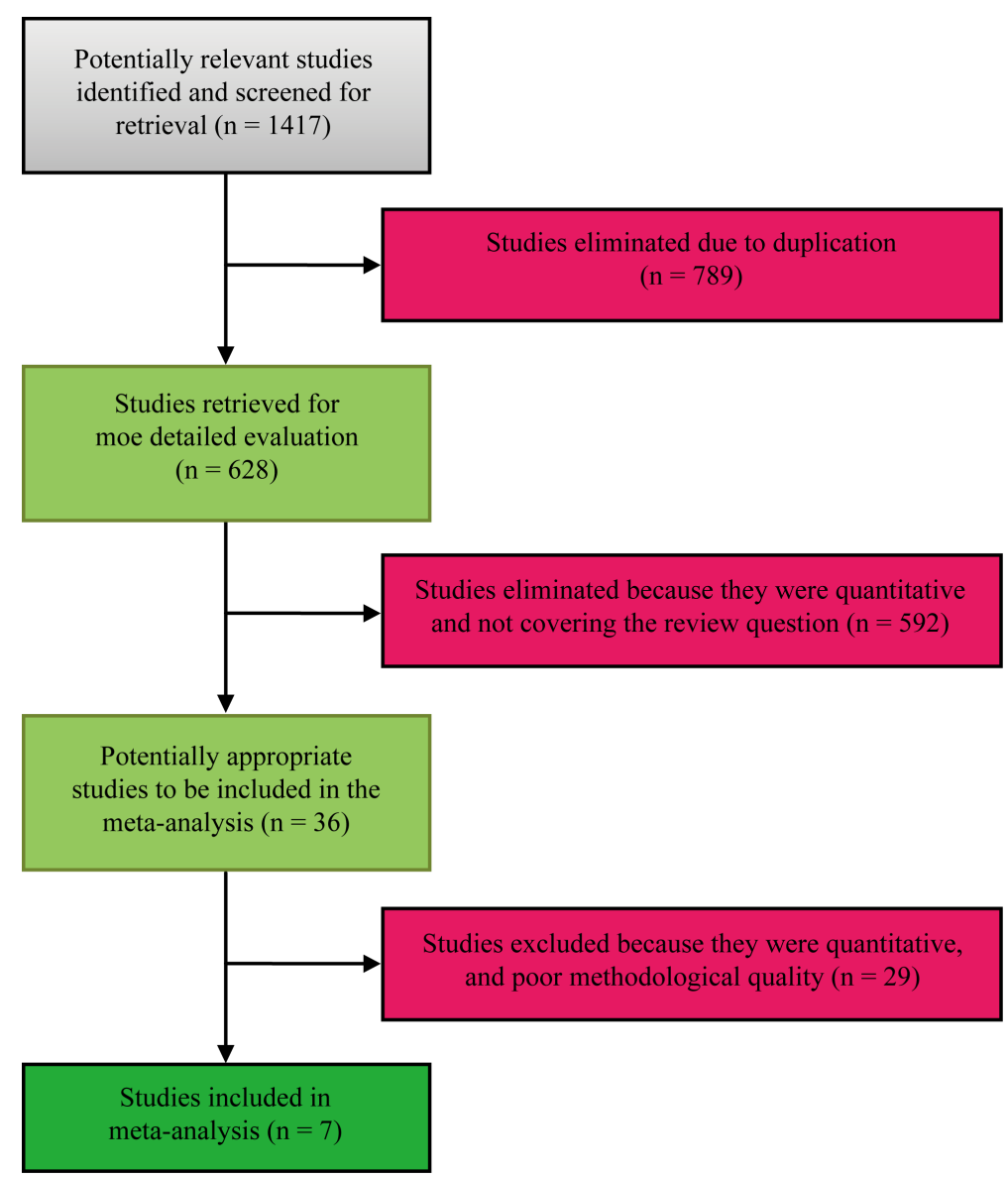

Figure 1. Flow chart for included studies.

\subsection{Assessment of Methodological Quality}

As part of the inclusion and exclusion criteria, the included studies were assessed for the validity, results and relevance against minimum criteria for adequacy of reporting detail on the sampling, data collection and analysis, rigour of the study elements indicating methodological soundness. This was done by three independent reviewers to avoid possible bias. The Joanna Briggs Institute-Qualitative Assessment and Review instrument (JBI-QARI) [14] was used to critically appraise the studies (Appendix 2). All the studies that met the criteria are listed in Table 2.

\subsection{Data Extraction}

Data were extracted from all the included papers by two reviewers and the third reviewer was consulted whenever necessary. Data extracted included Title of study, Author, Year of publication, Journal, Setting, Study Population, Objective, Methodology, Ethics, major Findings and Author's Conclusions. The standardised JBIQARI data extraction tool [14] (Appendix 3) was used to extract the data.

\subsection{Data Synthesis}

The process involved grouping the findings and rating them according to their credibility using the JBI degrees of Credibility scale [14] (Appendix 4). This was followed by categorising findings on the basis of similar meanings and then a thematic driven analysis to produce a single and comprehensive set of findings. Categorisation of findings was undertaken to identify common themes in the textual evidence. The identified categories were then further synthesised to produce a single synthesized theme. Six (6) themes emerged from the included studies. 
Table 2. Characteristics of articles selected for review.

\begin{tabular}{|c|c|c|c|c|c|c|c|}
\hline No. & Author & Year & Journal & Title & Setting & Design & $\begin{array}{l}\text { Number of } \\
\text { participants }\end{array}$ \\
\hline 1 & Cahill, H.A. & 1996 & $\begin{array}{l}\text { Journal of } \\
\text { Advanced } \\
\text { Nursing }\end{array}$ & $\begin{array}{c}\text { A Qualitative analysis of students' } \\
\text { experiences of mentorship }\end{array}$ & $\begin{array}{l}\text { Yorkshire district } \\
\text { hospital, UK }\end{array}$ & $\begin{array}{l}\text { Qualitative- } \\
\text { Focus Group } \\
\text { Discussions }\end{array}$ & $\begin{array}{c}233^{\text {rd }} \text { year } \\
\text { student nurses }\end{array}$ \\
\hline 2 & $\begin{array}{l}\text { Higgins, A. and } \\
\text { McCarthy, M. }\end{array}$ & 2005 & $\begin{array}{l}\text { Nurse Education } \\
\text { in practice }\end{array}$ & $\begin{array}{l}\text { Psychiatric nursing students' } \\
\text { experiences of having a mentor } \\
\text { during their first practice placement: } \\
\text { an Irish perspective }\end{array}$ & $\begin{array}{l}\text { Trinity college, } \\
\text { Dublin, Ireland }\end{array}$ & $\begin{array}{l}\text { Qualitative-semi } \\
\text { structured } \\
\text { interview guide }\end{array}$ & $\begin{array}{c}6 \text { first year } \\
\text { psychiatric } \\
\text { student nurses }\end{array}$ \\
\hline 3 & $\begin{array}{l}\text { Hughes, A.J. } \\
\text { and Fraser, } \\
\text { M.D. }\end{array}$ & 2011 & Midwifery & $\begin{array}{l}\text { There are guiding hands and there are } \\
\text { controlling hands: student midwives' } \\
\text { experiences of mentorship n UK }\end{array}$ & $\begin{array}{c}\text { University of } \\
\text { Nottingham, UK }\end{array}$ & $\begin{array}{c}\text { Focus Group } \\
\text { Discussions }\end{array}$ & $\begin{array}{c}581^{\text {st }}, 2^{\text {nd }} \text { and } \\
3^{\text {rd }} \text { year female } \\
\text { student midwives }\end{array}$ \\
\hline 4 & $\begin{array}{l}\text { Licquirish, S. } \\
\text { and Seibold, C. }\end{array}$ & 2008 & Midwifery & $\begin{array}{l}\text { Bachelor of Midwifery students' } \\
\text { experiences of achieving } \\
\text { competences; the role of the } \\
\text { midwifery preceptor }\end{array}$ & $\begin{array}{l}\text { Australian Catholic } \\
\text { University, } \\
\text { Victoria }\end{array}$ & $\begin{array}{l}\text { Grounded } \\
\text { theory-in-depth } \\
\text { interviews }\end{array}$ & $\begin{array}{l}8 \text { 3rd year } \\
\text { Midwifery } \\
\text { students }\end{array}$ \\
\hline 5 & $\begin{array}{l}\text { Ohrling, K. and } \\
\text { Hallberg, I.R. }\end{array}$ & 2000 & $\begin{array}{c}\text { International } \\
\text { Journal of } \\
\text { Nursing Studies }\end{array}$ & $\begin{array}{c}\text { Student nurses' lived experience } \\
\text { of preceptorship. Part 1-in relation } \\
\text { to learning }\end{array}$ & Sweden & $\begin{array}{l}\text { Phenomenology- } \\
\text { in-depth } \\
\text { Interview }\end{array}$ & $\begin{array}{l}173^{\text {rd }} \text { year } \\
\text { nursing } \\
\text { students }\end{array}$ \\
\hline 6 & $\begin{array}{l}\text { Ohrling, K. and } \\
\text { Hallberg, I.R. }\end{array}$ & 2000 & $\begin{array}{c}\text { International } \\
\text { Journal of } \\
\text { Nursing Studies }\end{array}$ & $\begin{array}{l}\text { Student nurses' lived experience } \\
\text { of preceptorship. Part 2-the } \\
\text { preceptor-preceptee relationship }\end{array}$ & $\begin{array}{l}\text { Northern College } \\
\text { of Nursing in } \\
\text { Northern Sweden }\end{array}$ & $\begin{array}{l}\text { Phenomenology- } \\
\text { in-depth } \\
\text { Interview }\end{array}$ & $\begin{array}{l}173^{\text {rd }} \text { year } \\
\text { nursing } \\
\text { students }\end{array}$ \\
\hline 7 & Watson, N.A. & 1999 & $\begin{array}{c}\text { Journal of } \\
\text { Advanced } \\
\text { Nursing }\end{array}$ & $\begin{array}{l}\text { Mentoring today-the students’ } \\
\text { views. An investigative case study } \\
\text { of pre-registration nursing students' } \\
\text { experiences and perceptions of } \\
\text { mentoring in one theory/practice } \\
\text { module of the common foundation } \\
\text { programme on a project } 2000\end{array}$ & $\begin{array}{l}\text { DeMontfort } \\
\text { University, } \\
\text { Charles Frear } \\
\text { Campus, UK }\end{array}$ & $\begin{array}{l}\text { Qualitative- } \\
\text { phenomenology- } \\
\text { semi structured } \\
\text { interview guide }\end{array}$ & $\begin{array}{l}35 \text { nursing } \\
\text { student } 15 \\
\text { mentors }\end{array}$ \\
\hline
\end{tabular}

\section{Review Findings}

\subsection{Description of the Studies and Methodological Quality}

Quality of the included seven (7) studies was high in methodological quality and in the data presented. Outlined below are the findings for the included studies as extracted using the JBI tool. A total of 29 findings (Table 3) were produced and these were aggregated and synthesised to produce six (6) synthesised themes as outlined under findings below.

\subsection{Findings}

From the systematic review, six themes emerged from the synthesised findings and these themes could be the basis for mentorship programme. The following are the themes that emerged from the synthesis themes are as listed below;

\subsubsection{Developing an Effective Mentor-Mentee Relationship before the Placement Is Vital for Learning}

The findings show that students would like to know the mentor who they are going to work with before they are sent to the placement area. Some of the students had this to say:

"No prior contact with mentors. Told about mentoring at the start of the module rather that the start of the course ([15], p. 260)".

One of the students shared her experience of her first day of her placement and how the mentor helped her settle:

"I was nervous going in the first morning and for her to sit down and explain what's going to happen, really puts your nerves at ease ([16], participant 5, pp. 220-221)". 
Table 3. Summary of major findings.

\begin{tabular}{|c|c|c|}
\hline Author/Year & Title & Major findings \\
\hline Cahill, H.A. (1996) & $\begin{array}{l}\text { A Qualitative analysis of students’ experiences } \\
\text { of mentorship }\end{array}$ & $\begin{array}{l}\text { 1) Impressions and expectations of student (C) } \\
\text { 2) Covert operations (U) } \\
\text { 3) A different job (C) }\end{array}$ \\
\hline $\begin{array}{l}\text { Higgins, A. and McCarthy, } \\
\text { M. (2005) }\end{array}$ & $\begin{array}{l}\text { Psychiatric nursing students’ experiences of having } \\
\text { a mentor during their first practice placement: } \\
\text { an Irish perspective }\end{array}$ & $\begin{array}{l}\text { 1) Someone there specially for you (U) } \\
\text { 2) Wanting the best out of the placement (U) } \\
\text { 3) Feedback for your own good (U) } \\
\text { 4) Supportive and professional relationship (U) } \\
\text { 5) Coping with being on your own (U }\end{array}$ \\
\hline $\begin{array}{l}\text { Hughes, A.J. and Fraser, } \\
\text { M.D. (2011) }\end{array}$ & $\begin{array}{c}\text { There are guiding hands and there are controlling } \\
\text { hands: student midwives' experiences of } \\
\text { mentorship n UK }\end{array}$ & $\begin{array}{l}\text { 1) Good and bad mentors (U) } \\
\text { 2) The relationship (U) } \\
\text { 3) Expectation of mentors (U) } \\
\text { 4) Different role models (U) } \\
\text { 5) Continuity with mentor (U) }\end{array}$ \\
\hline $\begin{array}{l}\text { Licquirish, S. and Seibold, } \\
\text { C. (2008) }\end{array}$ & $\begin{array}{c}\text { Bachelor of Midwifery students' experiences of } \\
\text { achieving competences; the role of the midwifery } \\
\text { preceptor }\end{array}$ & $\begin{array}{l}\text { 1) Inconsistence feedback (U) } \\
\text { 2) Continuity with preceptor/mentor (U) } \\
\text { 3) Hands on' (U) } \\
\text { 4) Increasing responsibility (U) } \\
\text { 5) Students are a burden (U) } \\
\text { 6) inconsistence midwifery procedural practice (U) }\end{array}$ \\
\hline $\begin{array}{l}\text { Ohrling, K. and Hallberg, } \\
\text { I.R. } 2000\end{array}$ & $\begin{array}{l}\text { Student nurses’ lived experience of preceptorship. } \\
\text { Part 1-in relation to learning }\end{array}$ & $\begin{array}{l}\text { 1) Directing learning (U) } \\
\text { 2) Learning in practical action (U) } \\
\text { 3) Feeling in learning (U) }\end{array}$ \\
\hline $\begin{array}{l}\text { Ohrling, K. and Hallberg, } \\
\text { I.R. (2000) }\end{array}$ & $\begin{array}{l}\text { Student nurses’ lived experience of preceptorship. } \\
\text { Part 2-the preceptor-preceptee relationship }\end{array}$ & $\begin{array}{l}\text { 1) Creating space for learning (U) } \\
\text { 2) Providing concrete illustrations (U) } \\
\text { 3) Exercising control (U) } \\
\text { 4) Seeking reflection (U) }\end{array}$ \\
\hline Watson, N.A. (1999) & $\begin{array}{l}\text { Mentoring today-the students' views. An investigative } \\
\text { case study of pre-registration nursing students’ } \\
\text { experiences and perceptions of mentoring in one } \\
\text { theory/practice module of the common foundation } \\
\text { programme on a project } 2000\end{array}$ & $\begin{array}{l}\text { 1) Preparation for Mentoring (C) } \\
\text { 2) Experiences (C) } \\
\text { 3) perception of mentoring (C) }\end{array}$ \\
\hline
\end{tabular}

Most of the students in the included studies indicated that a good mentor-mentee relationship is very important for learning in the clinical area. Students value this relationship as it makes them trust the mentor. Students expressed themselves in the following way:

"There was a kind of bond there; it wasn't friendship it was kept professional... She kept the boundaries of where you were ([16], participant 4, p. 222)".

Some students expressed that they did not have a good relationship with the mentor and this affected their placement experience. "I think the only thing for me and... it is related to practice but I didn't really get a relationship with the mentor I was working with and it really affected how I felt and how I felt um, confidence wise ([17], end of year 1 student, p. 480)".

Hughes and Fraser also echo that students always appreciated every interaction with the mentor as it facilitated learning "Someone who is willing to explain things and give you time to sort of learn new skills ([17], MMA $2^{\text {nd }}$ year, p. 479)".

Additionally it was reported by one student that "Working with someone who is caring and gives me the opportunity to make mistakes or practice skills...you know that if you do make a mistake, it's going to be OK. Um...so yeah...I suppose that's the way I learn best ([18], Cindy, p. 484)”.

\subsubsection{Continuity of Mentor and Diversity of Experience}

The studies in the review identified that students prefer to have continuity of mentorship with the same mentor throughout their placement. One of the students had this to say "If you've got one person that you work with all week who knows you and the kind of things you can do, it makes it a lot... than working with... like meeting a 
new person every day and they'll say to you, so what can you do? ([17], End of year one student, p. 481-482]”

"....because if you do something the way someone else told you... it might not be the way she [current midwife] told you ([18], Cindy, p. 486)”.

Another students said that "I think that if there was the preceptorship thing in every hospital, if you were able to work with one or two midwives for the whole placement ([18], Anna, p. 484)".

However, despite having one mentor throughout the placement, students wanted to see a variety of skill from different midwives"

"I think it's good to work with lots of midwives, then you can choose what you would do. Looking at what everybody else does, yeah, and you can pick bits from each one... ([17], $2^{\text {nd }}$ year student, p. 481)”.

\subsubsection{Hands on Practice to Develop Confidence and Competence}

From the review, three studies revealed that students want a mentor who allows them to practice the skill so that they develop confidence. In a study by Licqurish and Seibold [18], one student said; "If I'm sitting next to a woman and the CTG's on and there's dips... rather than just saying 'help'... I'm challenged to think what should I do in this situation, I'm not going to have someone next year ([18], Beth, p. 484)".

Another participant in Hughes and Fraser's study revealed that; "Some mentors want you to do anything and everything, and other mentors don't want you to do anything ([17], $2^{\text {nd }}$ year student, p. 481)".

Higgins and McCarthy also revealed that mentors allowed students to practice hands on when they were confident and students knew they would not be allowed hands on unless they have learnt some skill. "I knew she wouldn't let me do something unless I was able... Her having faith, gave me faith ([16], Participant 6, p. 221)".

"But now it falls into place, it's in my bones, yes; but the first time when she let me do it alone, oh my God, was it his right or left, was it really a green or a pink one, it was like you had a bad memory, because there was so much going on ([19], S-4, p. 17)".

\subsubsection{Feedback Is Important for Development}

From the reviewed studies, the students appreciate a mentor who gives them constructive feedback. They believe that when you are given feedback, you identify your weakness and you are able to improve. In Licquirish and Seibold one student had this to say;

I prefer some of them will debrief a birth with you straight afterwards, some of them won't even bother, like they won't even check third stage with you ([18], Anna, p. 483-484)".

Another student explained that a mentor who gives you feedback has good intentions for you to progress in your profession.

"You knew she want you to improve and do better next time ([16], participant 1, p. 222)".

In Hughes and Fraser some students expressed themselves as follows; "it is good to have someone who is willing to explain things and give you time to sort of learn new skills ([17], MMA $2^{\text {nd }}$ year, p. 479)”.

In Cahill, one student felt that some mentors were not open enough to give constructive feedback. Some mentors are not honest to the mentee when they give feedback.

"Things aren't openly discussed on the ward, what they say to you and what they write down in your report are two different things, often they'll be saying negative things to you, and then you'll get really nice report, and you think, why aren't they honest? ([20], p. 795)”.

\subsubsection{Feeling Confident to Practice When Mentor Demonstrates and Observes}

The studies reviewed revealed that students appreciate the demonstrations of skills the mentor makes while the student observes. This was said to be helpful in building students' confidence to try the skill

"I think it is just that I have been able first to see how she does it and then you have learnt at college to do it in a special way and then later to see how she does it: and she tells you why she does it in the way she does ([21], S-8, p. 31).”

"...even taking a blood sample, which I had done in... I want to see their routine and their... what they use, because you want to see; everybody does it a little different and so on... ([19], S-16, p.19)”.

Students also expressed a feeling that they would love the mentor to take some time to observe the students perform a skill. This helps them know whether they are doing the right thing.

"Even if she observes me, so I think she is my $(P)$ and she should watch. To be able to tell me if I do something wrong and what I can do better or if it was OK ([19], S-9, p. 28)". 


\subsubsection{Feeling Unsupported when Designated Mentor Is off Duty}

According to the studies reviewed, some students experienced lack of support when their mentor is off duty. Other staff were not willing to help the students. In a study done by Watson, one student had this to say;

"No planned programme in mentor's absence. Felt burden to staff. When mentor is on different shift [15]".

Students also observed that other staff were too busy to help the students when the mentor was not available. Students felt out of place and reported that sometimes they did more work than learning. Some students had this to say"

"...they'd be so busy; you sort of felt a nuisance... I felt more in the way when she [mentor] wasn't there... ([16], participant 2, p. 223)”.

"I know students can be a pain in the bum sometimes, because... they hinder... the way you work and all kind of stuff ([18], Cindy, p. 486)".

Because of lack of support when the mentor is off duty, students feel frustrated and as a result they do not learn but just work.

"It was the most stressful ward I've been on and I was really frustrated because I felt I was learning nothing and just doing all the work ([20], p. 795)".

\section{Discussion}

The aim of this study was to report a synthesis of the perceptions and experiences of nursing and midwifery students regarding mentorship. Mentorship being one of the methods adopted to support student during clinical placement has been used for long time. The review question was 'What are the perceptions and experiences of nursing and midwifery students regarding mentorship during clinical placement? The review has illuminated a number of experiences students undergo during clinical placement with their mentors varying from developing a good relationship with the mentor for effective learning, being given feedback, having continuity of mentorship while having a diverse range of experiences with other staff members. The review also reports that students perceive hands on practice as one way of gaining confidence and competence. This review also highlights the fact that students experience lack of support from other staff members when their assigned mentor is off duty.

Developing an effective mentor-mentee relationship before the placement is vital for learning. The feelings of students are that a mentor mentee relationship should be started before the placement. This allows for the both the mentor and mentee to prepare and get to know each other. Watson [15] also indicated that usually students do not have any contact with the mentor until time of their placement. This may contribute to a poor relationship between mentor and mentee during placement which conversely affects students' learning. Furthermore this finding highlights the importance of the placement coordinator who makes arrangements for the mentor-mentee to get to know each other. According to Zachary and Andrews et al. communication should begin before the actual face to face encounter as this helps the student feel at ease as he or she prepares to meet the mentor who is a total stranger [22] [23]. Therefore the preparation for both the mentor and the mentee would be helpful to allow time to build a relationship in case where mentors are allocated. The better the mentoring relationship starts, the better and faster they start experiencing results.

Clinical placement make students nervous as they do not know what they expect, and therefore knowledge of someone who is there to welcome the students makes them feel supported. A good relationship is perceived as the basis for effective mentoring and this is thought to be based on a mutual relationship between the student and the mentor. According to Cahill, Hughes and Fraser, students appreciate the relationship as it has a big impact on their learning of the skills and building of their confidence. Interestingly, students also value the mentor who maintains good relationship with clients/patients. This highlights the passion students have in having a mentor who portrays professionalism [16] [20] [24].

This therefore entails that mentors should show good qualities as they mentor students. These qualities of a mentor are also attributed to the type of relationship and students felt some of the good qualities in a mentor as being supportive, helpful and committed to the relationship [6] [20] [25]. This is thought to have a positive influence in the students' learning as there is consistency, genuineness and respect in the relationship.

Continuity of mentor is an essential component of a lasting relationship between mentor and mentee. While this may not be a problem to some students, others would want to have a named mentor who thy will work with almost all the time. This means that the student is able to learn the skill from one skilled mentor [17]. However this preference is mainly found among the junior students, having their first placement when they need 
more support. More senior students also appreciated diverse working experiences with different staff members to learn and compare skills from different staff members. D'Souza et al. also emphasises that involvement of students in diverse experiences promotes their growth, motivation and critical thinking abilities. This therefore should be an encouragement to all staff members to keep up to date their professional skill in order to avoid confusing the student [26]. Despite all these preferences, students want to have someone with whom they can have a mentor-mentee relationship, while having the freedom to work with other available staff [18].

"Hands on" practice to develop competence and confidence. There is an old saying that, "practice makes perfect”. The development of confidence and competence in practice is the overall goal of students' clinical placement programmes. This cannot take place at one time but involves a systematic progression as described by the Dreyfus model [27]. This progression requires repeated practice to reach the competent level of practice.

Students' exposure to skills and "hands on experience" is perceived as a good way of helping them grow their skills and develop their confidence [17] [18] [21] It is important that the mentor gives the student some time to practice. Students valued this opportunity their placements provided for linking theory to practice, of developing communication skills and of increasing independence. The hands on practice help them learn new skills and also interact with other members of staff and also the clients. This helps them link theory with practice

Myall et al. notes that students viewed the mentor as the key person to create learning opportunities so that they get the maximum out of the placement experience. Having to experience and to practice a wide range of skills exposes the students to real life situations [6]. While students appreciate observing their mentors practicing, they also want some independence to meet the challenging situations and be able to make decisions as this increase their responsibility. This builds their confidence and ability to use critical thinking and reflection to solve everyday practice issues.

However, not all mentors create space for students to gain freedom of practice and this results in students lacking confidence in themselves because they have been restricted in their practice and they heavily rely on others for decision making [17]. In today's health care system the challenges require graduates who are able to make quality decision and practice autonomously while working with other colleagues. It is well acknowledged that learning is most effective when students are given opportunities to engage actively in real life activities, however demanding it may be.

Feedback is an integral part of the learning process and ultimately on one's professional development. Without feedback mistakes students make are not corrected and those who are performing well are not encouraged. Learning therefore may not take place. While students appreciate the interaction they have with mentors and staff alike they valued working with a mentor who is supportive, shares knowledge, provides constructive feedback and creates a time for debriefing and reflection on the practice [18] [19] Students who have time with the mentor to reflect on the nursing actions and get feedback feel a sense of achievement

It is worth mentioning that students sometimes feel that mentors and staff give inconsistent feedback to students [18] [21]. Mentors give reports contrary to what they say about the student. This can be related to what Duffy (2004) [28] reports that mentors fail to fail students despite condemning them. Because of lack of consistent constructive feedback, some students have not appreciated the mentors' contribution. While feedback is appreciated, negative feedback prevents students from trying new skills, and this means the student will remain unskilled in most of the clinical tasks [29].

\section{Feeling confident to practice when mentor demonstrates and observes.}

During clinical placement, student regard the mentor as a model and they perceive a mentor to be skilful and qualified and they want to observe their mentor demonstrate a skill as it gives them confidence to try by themselves [19].

Not only do they want to observe, but they want to be observed by the mentor while they practice a procedure as this makes them feel safe, knowing a more skilled staff member is available to correct and direct them. Higgins and McCarthy [16] and Steele [30] echo the same sentiment that the confidence students have in their mentors help them develop their own confidence. Purposeful observation of the learner will help the mentor protect the integrity of the patient under her/his care. This therefore means, the mentor should be knowledgeable and have quality skills to be able to transfer these skills to the mentee.

While it is appreciated that having a named mentor is helpful to the learners, students sometimes feel unsupported when the designated mentor is off duty. This problem can be associated with having the mentor's shifts not coincide with that of the mentee. Findings of this review indicate that there is usually no arrangement made for the student when the mentor is away [15] [16] [18]. 
A situation like this seems to interrupt student learning and other staff members are sometimes not willing to assist the student, making the student feel unwanted, a burden or an inconvenience. This is in agreement with one of the early studies by Philips et al. [31] who noted that when the named mentor was not around, students were reduced to standing around idle and sometimes forced to do more work than learning. This finding is in agreement with the study of Kilcullen [32] who also noted that students sometimes felt unsupported during clinical placement and this was attributed to the fact that mentors also lacked support from the ward managers. From the review it is also clear that there is minimal support for the mentors from the managers. Cahill (1996) mentions that the role of mentors is not well understood in the clinical setting. Because of this, they are allowed less time to teach students because of the busy schedules [20]. The managers need to recognise the mentors' role and support then even when they are off duty by supporting the students in their absence.

However, on the contrary, Lloyd Jones et al. [33] noted that some students thought it was not a problem for them when the mentor was not available. Planning of the students' experience will become an important issue if students are to have continuity of support during clinical placement. Educators need to involve the whole team of health professional in supporting student/trainee learning.

\subsection{Conclusions and Implications}

Mentorship plays an important role in shaping how the students will subsequently practice as a qualified nurse or midwife. Although applied differently in different institutions, mentorship still stands out to be a good method of teaching and assessing students in clinical settings. It is clear that there are many lessons to be learnt in order to continue improving mentorship or to develop a good mentorship programme. It can also be concluded that mentorship will be beneficial to students if a good relationship is established between the mentor and mentee, as this is the beginning of the experience. Despite having designated mentors, the overall interaction students have with all members of staff during clinical placement is essential for effective learning. A friendly and yet supportive environment where feedback is given is central to the learning of students. Finally, all staff members should be willing to support students in learning and they should be able to give constructive feedback to the students about their progress for the students to learn and develop the knowledge, skill and attitudes that are necessary to their learning.

\subsection{Implication for Nursing and Midwifery Practice}

Despite the fact only seven studies are included in the review, the findings have a potential to impact on nursing and midwifery practice if taken into consideration. The review has highlighted a number of important issues regarding nursing and midwifery practice and students' clinical learning. Firstly, students respect qualified staff to learn the skill of their chosen profession from them and this can have an influence on what type of health professional they will eventually become. This means that the mentor and other staff alike should be well vested with knowledge and skills to educate and train the students according to the required professional standard. However, from this review, it would appear that students are sometimes left with doubts because of the inconsistencies in practice among the qualified staff which can have a major impact on their learning. Consequently, having some form of standardised practice among the staff could help in alleviating this and avoid confusing students. Students should always be supported during clinical placement when their mentor is absent as lack of support has an impact on clinical placement experience.

\subsection{Implications for Research}

The review revealed that there had been little primary research undertaken to examine the perceptions and experiences of students regarding mentorship during clinical placements. Some of the research retrieved used quantitative methods which did not bring out the lived experiences of the mentor and mentee and so were not appropriate for the review. As this review examined mentoring in the context of nursing and midwifery collectively, it is difficult to extrapolate any specific differences between the two professions. As such, it would be appropriate for further research to be undertaken to specifically examine midwifery students' and midwives perception and experiences of mentorship. A further challenge for future research would be to explore the views of students towards named mentors as this was not fully apparent in the reviewed studies. This could help understand the impact a named or selected mentor has on the mentoring relationship. 


\section{Limitations}

While the reviewer did an extensive search of studies from various databases, certain studies were inaccessible. This review examined mentoring in the context of nursing and midwifery collectively, it was difficult to extrapolate any specific differences between the two professions.

The review revealed that a lack of studies about mentorship from the African context where it was anticipated the findings of this review would be used to implement a mentorship scheme for student midwives. All the seven studies were from Europe and so it might be questioned whether the findings could be transferable to other settings.

\section{Acknowledgements}

This work was part of the support received from the International Office Nottingham Developing Solution Scholarship.

\section{Conflict of Interest}

No conflict of interest to be declared.

\section{References}

[1] Piercey, C. (2014) Collaboration between the Community and Tertiary Nurse Education in Bridging the Gap between Theory and Practice. Category: Refereed Professional Practice.

[2] Dean, J. and Kenworthy, N. (2000) The Principles of Learning. In: Nicklin, P.J. and Kenworthy, N., Eds., Teaching and Assessing in Nursing Practice: An Experiential Approach, BailliereTindall, Edinburgh, 45-66.

[3] ICM (2010) Global Standards for Midwifery Education. http://www.internationalmidwives.org

[4] UNFPA (2011) The State of the World’s Midwifery 2011. Delivering Health: Saving Lives. UNFPA, New York.

[5] WHO (2009) Global Standards for the Initial Education of Professional Nurses and Midwives. Nursing \& Midwifery Human Resources for Health, World Health Organization, Geneva. http://www.who.int/hrh/nursing_midwifery/hrh_global_standards_education.pdf

[6] Myall, M., Levett-Jones, T. and Lathlean, J. (2008) Mentorship in Contemporary Practice: The Experiences of Nursing Students and Practice Mentors. Journal of Clinical Nursing, 17, 1834-1842. http://dx.doi.org/10.1111/j.1365-2702.2007.02233.x

[7] Dennis-Antwi, J.A. (2011) Preceptorship for Midwifery Practice in Africa: Challenges and Opportunities. Evidence Based Midwifery, 9, 137-142.

[8] Cope, P., Cuthbertson, P. and Stoddart, B. (2000) Situated Learning in the Practice Placement. Journal of Advanced Nursing, 31, 850-856. http://dx.doi.org/10.1046/j.1365-2648.2000.01343.x

[9] Napthine, R. (1996) Clinical Education: A System under a Pressure. Australian Nursing Journal, 3, 20-24.

[10] Anderson, E.M. and Shannon, A.L. (1988) Toward a Conceptualization of Mentoring. Journal of Teacher Education, 39, 38-42. http://dx.doi.org/10.1177/002248718803900109

[11] NMC (2008) Standards to Support Learning and Assessment in Practice: NMC Standards for Mentors, Practice Teachers and Teachers. Nursing and Midwifery Council, London.

[12] Nettleton, P. and Bray, L. (2008) Current Mentorship Schemes Might Be Doing Our Students a Disservice. Nurse Education in Practice, 8, 205-212. http://dx.doi.org/10.1016/j.nepr.2007.08.003

[13] Centre for Reviews and Dissemination (viewed 12/07/12) DARE (Database of Abstracts of Reviews of Effects). University of York, York. www.crd.york.ac.uk/crdweb/

[14] JBI (2011) Joanna Briggs Institute Reviewers’ Manual. 2011 Edition, University of Adelaide, Adelaide.

[15] Watson, N.A. (1999) Mentoring Today-The Students' Views. An Investigative Case Study of Pre-Registration Nursing Students' Experiences and Perception of Mentoring in One Theory Practice Module of the Common Foundation Programme on a Project 2000 Course. Journal of Advanced Nursing, 29, 254-262. http://dx.doi.org/10.1046/j.1365-2648.1999.00881.x

[16] Higgins, A. and McCarthy, M. (2005) Psychiatric Nursing Students’ Experiences of Having a Mentor during Their First Practice Placement: An Irish Perspective. Nurse Education in Practice, 5, 218-224. http://dx.doi.org/10.1016/j.nepr.2004.12.002 
[17] Hughes, J.A. and Fraser, M.D. (2011) “There Are Guiding Hands and There Are Controlling Hands”: Student Midwives Experience of Mentorship in the UK. Midwifery, 27, 477-483. http://dx.doi.org/10.1016/j.midw.2010.03.006

[18] Licquirish, S. and Seibold, C. (2008) Bachelor of Midwifery Students' Experiences of Achieving Competence: The Role of the Midwife Preceptor. Midwifery, 24, 480-489. http://dx.doi.org/10.1016/j.midw.2007.05.001

[19] Ohrling, K. and Hallberg, I.R. (2000) Student Nurses’ Lived Experiences of Preceptorship. Part 2-The PreceptorPreceptee Relationship. International Journal of Nursing Studies, 37, 25-36. http://dx.doi.org/10.1016/S0020-7489(99)00055-3

[20] Cahill, H.A. (1996) A Qualitative Analysis of Student Nurses' Experiences of Mentorship. Journal of Advanced Nursing, 24, 791-799. http://dx.doi.org/10.1046/j.1365-2648.1996.25618.x

[21] Ohrling, K. and Hallberg, I.R. (2000) Student Nurses' Lived Experiences of Preceptorship. Part 1-In Relation to Learning. International Journal of Nursing Studies, 37, 13-23. http://dx.doi.org/10.1016/S0020-7489(99)00054-1

[22] Zachary, L. (2000) The Mentor’s Guide: Facilitating Effective Learning Relationships.

[23] Andrews, M. and Wallis, M. (1999) Mentorship in Nursing: A Literature Review. Journal of Advanced Nursing, 29, 201-207. http://dx.doi.org/10.1046/j.1365-2648.1999.00884.x

[24] Barondess, J.A. (1997) On Mentoring. Journal of Royal Society of Medicine, 90, 347-349.

[25] Wilkes, Z. (2006) The Student-Mentor Relationship: A Review of the Literature. Nursing Standard, 20, 42-47. http://dx.doi.org/10.7748/ns2006.05.20.37.42.c4160

[26] D’ Souza, M.S., Venkatesaprumal, R., Rudhakrishnan, J. and Balachandran, S. (2013) Engagement in Clinical Learning Environment among Nursing Students: Role of Nurse Educators. Open Journal of Nursing, 3, 25-32. http://dx.doi.org/10.4236/ojn.2013.31004

[27] Benner, P. (1984) From Novice to Expert: Excellence and Power in Clinical Nursing Practice. American Journal of Nursing, 84, 1480. http://dx.doi.org/10.1097/00000446-198412000-00027

[28] Duffy, K. (2004) Mentors Need More Support to Fail Incompetent Students. British Journal of Nursing, 13, 582. http://dx.doi.org/10.12968/bjon.2004.13.10.13042

[29] Warren, D. (2010) Facilitating Pre-Registration Nurse Learning: A Mentor Approach. British Journal of Nursing, 19, 1364-1367. http://dx.doi.org/10.12968/bjon.2010.19.21.80001

[30] Steele, R. (2009) Gaining Competence and Confidence as a Midwife. British Journal of Midwifery, 17, 441-447.

[31] Phillips, R., Davies, W.B. and Neary, M. (1996) The Practitioner-Teacher: A Study in the Introduction of Mentors in the Preregistration Nurse Education Programme in Wales: Part 2. Journal of Advanced Nursing, 23, 1080-1088. http://dx.doi.org/10.1046/j.1365-2648.1996.01163.x

[32] Kilcullen, N.M. (2007) Said Another Way: Impact of Mentorship on Clinical Learning. Nursing Forum, 42, 95-104. http://dx.doi.org/10.1111/j.1744-6198.2007.00073.x

[33] Lloyd Jones, M., Walters, S. and Akehurst, R. (2001) The Implications of Contact with the Mentor for Preregistration Nursing and Midwifery Students. Journal of Advanced Nursing, 35, 151-160.

http://dx.doi.org/10.1046/j.1365-2648.2001.01832.x 
Appendix 1: Excluded Studies

\begin{tabular}{|c|c|c|c|c|c|}
\hline No. & Author(s) & Year & Title & Design & Reason for Exclusion \\
\hline 1 & AltuntasSerap & 2011 & $\begin{array}{l}\text { Mentorship relations among academician } \\
\text { nurses in Turkey: An assessment from the } \\
\text { viewpoints of mentors and mentees }\end{array}$ & Quantitative & Methodology \\
\hline 2 & Andrea Cropper & 2000 & $\begin{array}{l}\text { Mentoring as an inclusive device for the } \\
\text { excluded: Black students' experience of a } \\
\text { mentoring scheme, Social Work Education }\end{array}$ & Expert opinion & Not a study \\
\hline 3 & $\begin{array}{l}\text { Andrews G J, Brodie D A., } \\
\text { Andrews J P., Hillan E, } \\
\text { Thomas G, Wong J. } \\
\text { and Rixon }\end{array}$ & 2006 & $\begin{array}{l}\text { Professional roles and communications } \\
\text { in clinical placements: A qualitative } \\
\text { study of nursing students' perceptions } \\
\text { and some models for practice }\end{array}$ & Qualitative & $\begin{array}{l}\text { Focused on general clinical } \\
\text { experience }\end{array}$ \\
\hline 4 & $\begin{array}{l}\text { Andrews, M., \& } \\
\text { Chilton, F. }\end{array}$ & 2000 & $\begin{array}{l}\text { Student and mentor perceptions of } \\
\text { mentoring effectiveness }\end{array}$ & Quantintative & methodology \\
\hline 5 & Burnard P. & 1990 & $\begin{array}{l}\text { The student experience adult learning } \\
\text { and mentorship revisited }\end{array}$ & & Expert paper \\
\hline 6 & $\begin{array}{l}\text { Chapman Rose and } \\
\text { Orb Angelica, }\end{array}$ & 2001 & $\begin{array}{c}\text { Coping strategies in clinical practice: } \\
\text { The nursing students' lived } \\
\text { experience }\end{array}$ & qualitative & $\begin{array}{l}\text { Focused on students coping with } \\
\text { demands of clinical placement } \\
\text { rather than mentorship }\end{array}$ \\
\hline 7 & Chesser-Smyth Patricia A. & 2005 & $\begin{array}{c}\text { The lived experiences of general student } \\
\text { nurseson their first clinical placement: } \\
\text { A phenomenological study }\end{array}$ & Qualitative & $\begin{array}{c}\text { Focused on general clinical } \\
\text { placement experience and does } \\
\text { not look at mentorship }\end{array}$ \\
\hline 8 & $\begin{array}{l}\text { Coates, V E and } \\
\text { Gormley, E }\end{array}$ & 1997 & $\begin{array}{l}\text { Learning the practice of nursing: } \\
\text { views about preceptorship }\end{array}$ & Mixed method & $\begin{array}{l}\text { Methodology and the } \\
\text { main focus was the } \\
\text { views of the precptors }\end{array}$ \\
\hline 9 & Earnshaw Graham & 1995 & Mentorship; student's views & Qualitative & $\begin{array}{l}\text { Method of data collection } \\
\text { not very clear (Survey) }\end{array}$ \\
\hline 10 & $\begin{array}{l}\text { Gidman J, McIntosh A, } \\
\text { Melling K and Smith D }\end{array}$ & 2011 & $\begin{array}{l}\text { Student perceptions of } \\
\text { support in practice }\end{array}$ & Mixed method & $\begin{array}{l}\text { Explored general support } \\
\text { from the clinical area and } \\
\text { not the mentor }\end{array}$ \\
\hline 11 & Gray M.A. and Smith L.N & 2000 & $\begin{array}{l}\text { The qualities of an effective mentor from } \\
\text { the student nurse's perspective: findings } \\
\text { from a longitudinal qualitative study }\end{array}$ & & $\begin{array}{l}\text { Focused on qualities } \\
\text { of a mentor }\end{array}$ \\
\hline 12 & $\begin{array}{c}\text { Huybrecht S., Loeckx W., } \\
\text { Quaeyhaegens Y, } \\
\text { De Tobel D and Mistiaen }\end{array}$ & 2011 & $\begin{array}{l}\text { Mentoring in nursing education: } \\
\text { Perceived characteristics of mentors } \\
\text { and the consequences of mentorship }\end{array}$ & $\begin{array}{l}\text { Questionnaire } \\
\text { survey }\end{array}$ & $\begin{array}{l}\text { Focused on the mentors } \\
\text { and not students }\end{array}$ \\
\hline 13 & Midgley K. & 2006 & $\begin{array}{l}\text { Pre-registration student nurses p, } \\
\text { erception of the hospital-learning } \\
\text { environment during clinical placements }\end{array}$ & quantitative & $\begin{array}{l}\text { The focus was on general } \\
\text { learning environment } \\
\text { in clinical setting }\end{array}$ \\
\hline 14 & $\begin{array}{c}\text { Mousa Alavi, Khosrow } \\
\text { Tavakol, Mahdi Behzadnejad } \\
\text { and Khalil Mahdi Zadeh }\end{array}$ & 2008 & $\begin{array}{c}\text { Iranian nurse students' experiences } \\
\text { of relationships with nurses in } \\
\text { clinical setting }\end{array}$ & Qualitative & $\begin{array}{l}\text { The focus was on general } \\
\text { clinical experience and not } \\
\text { mentorship/preceptorship }\end{array}$ \\
\hline 15 & $\begin{array}{l}\text { Myall M, Levett-Jones T } \\
\text { and Lathlean J }\end{array}$ & 2008 & $\begin{array}{l}\text { Mentorship in contemporary practice: } \\
\text { the experiences of nursing students } \\
\text { and practice mentors }\end{array}$ & Mixed method & Methodology \\
\hline 16 & $\begin{array}{l}\text { Nabolsia M., Zumotb A., } \\
\text { Wardamc L. and } \\
\text { Abu-Moghlid F }\end{array}$ & 2012 & $\begin{array}{l}\text { The experience of Jordanian nursing } \\
\text { students in their clinical practice }\end{array}$ & Quantitative & Methodology \\
\hline 17 & $\begin{array}{l}\text { Ohrling K. and } \\
\text { Hallberg IR. }\end{array}$ & 2001 & $\begin{array}{l}\text { The meaning of preceptor: nurses’ lived } \\
\text { experience of being a preceptor. }\end{array}$ & Qualitative & $\begin{array}{l}\text { Focused on preceptors } \\
\text { and not students }\end{array}$ \\
\hline
\end{tabular}




\section{Continued}

\begin{tabular}{|c|c|c|c|c|c|}
\hline 18 & $\begin{array}{l}\text { Papastavrou E, Lambrinou E, } \\
\text { Tsangari H, Saarikoski M, } \\
\text { and Leino-Kilpi H }\end{array}$ & 2010 & $\begin{array}{l}\text { Student nurses experience of learning } \\
\text { in the clinical environment. }\end{array}$ & Quantitative & $\begin{array}{l}\text { The methodology and the } \\
\text { study focused on general } \\
\text { clinical experience }\end{array}$ \\
\hline 19 & $\begin{array}{l}\text { Papp I, Markkanen M, } \\
\text { and von Bonsdorff } \mathrm{M}\end{array}$ & 2003 & $\begin{array}{l}\text { Clinical environment as a learning } \\
\text { environment: student nurses’ } \\
\text { perceptions concerning clinical } \\
\text { learning experiences }\end{array}$ & $\begin{array}{l}\text { Qualitative- } \\
\text { phenomenology }\end{array}$ & $\begin{array}{l}\text { The study focuses on } \\
\text { experiences in the clinical } \\
\text { environment and not } \\
\text { specifically with mentors }\end{array}$ \\
\hline 20 & $\begin{array}{l}\text { Pearcey PA. and } \\
\text { Elliott BE. }\end{array}$ & 2004 & $\begin{array}{l}\text { Student impressions of } \\
\text { clinical nursing }\end{array}$ & Qualitative & $\begin{array}{l}\text { Not specific to mentorship but } \\
\text { general clinical experience }\end{array}$ \\
\hline 21 & Peirce, A. G. & 1991 & $\begin{array}{l}\text { Preceptorial students' view of } \\
\text { their clinical experience }\end{array}$ & Qualitative & $\begin{array}{l}\text { The focus was on general } \\
\text { clinical experience }\end{array}$ \\
\hline 22 & Prevost M. & 2011 & $\begin{array}{l}\text { Mentorship: an appraisal from a } \\
\text { student midwife's perspective }\end{array}$ & & The paper is an appraisal \\
\hline 23 & $\begin{array}{l}\text { Saarikoski M., Marrow C., } \\
\text { Abreu W., Riklikiene O. } \\
\text { and O”zbicak S. }\end{array}$ & 2007 & $\begin{array}{c}\text { Student nurses' experience of supervision } \\
\text { and Mentorship in clinical practice: } \\
\text { A cross cultural perspective }\end{array}$ & Survey & $\begin{array}{l}\text { The paper is more of } \\
\text { quantitative than qualitative }\end{array}$ \\
\hline 24 & Sharif F. and Masoumi S. & 2005 & $\begin{array}{l}\text { A qualitative study of nursing student } \\
\text { experiences of clinical practice }\end{array}$ & Qualitative & $\begin{array}{l}\text { Focuses on general clinical } \\
\text { experiences }\end{array}$ \\
\hline 25 & $\begin{array}{l}\text { Suen L.K.P. and } \\
\text { Chow F.L.W }\end{array}$ & 2001 & $\begin{array}{c}\text { Students' perceptions of the effectiveness } \\
\text { of mentors in an undergraduate nursing } \\
\text { programme in Hong Kong }\end{array}$ & Qualitative & $\begin{array}{l}\text { The focus was on the } \\
\text { role of the mentor }\end{array}$ \\
\hline 26 & $\begin{array}{l}\text { vanEps MA., Cooke M., } \\
\text { Creedy DK. And Walker R }\end{array}$ & 2006 & $\begin{array}{l}\text { Student evaluation of a year-long } \\
\text { mentorship program: A quality } \\
\text { improvement initiative }\end{array}$ & Evaluation & Methodology \\
\hline 27 & Wareing M. & 2011 & $\begin{array}{l}\text { Workplace mentor support for Foundation } \\
\text { degree students: a hermeneutic } \\
\text { phenomenological study }\end{array}$ & Qualitative & Focuses on staff nurses \\
\hline 28 & $\begin{array}{l}\text { Warne T, Johansson U, } \\
\text { Papastavrou E, Tichelaar E, } \\
\text { Tomietto M, Van den } \\
\text { Bossche K, Moreno MF V, } \\
\text { and Saarikoski M }\end{array}$ & 2010 & $\begin{array}{l}\text { An exploration of the clinical learning } \\
\text { experience of nursing students in nine } \\
\text { European countries }\end{array}$ & Qualitative & $\begin{array}{l}\text { Focuses on clinical } \\
\text { placement in general } \\
\text { and the nurse teacher }\end{array}$ \\
\hline 29 & Woodrow Philip & 1994 & $\begin{array}{l}\text { Mentorship: perceptions and pitfalls } \\
\text { for nursing practice }\end{array}$ & Not clear & Expert paper \\
\hline
\end{tabular}




\title{
Appendix 2: JBI-QARI Critical Appraisal Form Used to Appraise the Articles
}

Author: Record Number:

Journal: Year:

Reviewer:

Article:

\section{Criteria}

1) There is congruity between the stated philosophical perspective and the research methodology

2) There is congruity between the research methodology and the research question or objectives

3) There is congruity between the research methodology and the methods used to collect data

4) There is congruity between the research methodology and the representation and analysis of data

5) There is congruity between the research methodology and the interpretation of results

6) There is a statement locating the researcher culturally or theoretically

7) The influence of the researcher on the research, and vice-versa, is addressed

8) Participants, and their voices, are adequately represented

9) The research is ethical according to current criteria or, for recent studies; there is evidence of ethical approval by an appropriate body

10) Conclusions drawn in the research report do appear to flow from the analysis, or interpretation, of the data

\section{Total}

Reviewers Comments: Accept/Reject

Source: Joanna Briggs Institute (2011) Joanna Briggs Institute Reviewers’ Manual: 2011 edition. University of Adelaide.

\section{Appendix 3: JBI-QARI Data Extraction Form; Qualitative Data Extraction Tool}

\author{
Methodology \\ Method \\ Data Analysis \\ Setting \& Context \\ Geographical Context \\ Cultural Context \\ Participants \\ Number: \\ Description: \\ Phenomena of Interest
}

Findings Narrative Description Quality of the Evidence Rating (U, C orUs)

\section{Authors' conclusion}

Comments

Limitations

Source: Joanna Briggs Institute (2011) Joanna Briggs Institute Reviewers’ Manual: 2011 edition. University of Adelaide. 


\section{Appendix 4: JBI-QARI Degrees of Credibility Scale (JBI, 2011)}

- Unequivocal (U): the evidence that is beyond reasonable doubt and includes findings that are factual, directly reported or observed, and is not open to challenge.

- Credible (C): evidence that, while interpretative, is plausible in light of the data and theoretical framework. Conclusions can be logically inferred from the data but, because the findings are essentially interpretive, these conclusions are open to challenge.

- Unsupported (Us): when none of the other level descriptors apply and when, most notably, findings are not supported by the data. 